\title{
Clinical use of pharmacogenomics
}

\author{
Amalio Telenti \\ From 17th International Symposium on HIV and Emerging Infectious Diseases (ISHEID) \\ Marseille, France. 23-25 May 2012
}

The expanding list of antiretroviral drugs, the increasing possibilities in therapy of $\mathrm{HCV}$ and other co-infections represent an attractive setting for individualized prescription. However, there has been considerable hype, and limited impact of pharmacogenetics in care.

The development of pharmacogenetic tools would be of interest considering the complexity of treatment, the cost, and the expectation of long-term exposure. It would also be desirable given the possibility of serious toxicity, but also treatment intolerance, cumulative toxicity or the unfavorable interaction of drugs and aging, metabolic, cardiovascular and bone disease processes.

This presentation will review available tests, the position of agencies on the inclusion of pharmacogenetic information in labels, and a perspective on developments in genomic medicine.

Published: 25 May 2012

doi:10.1186/1742-4690-9-S1-12

Cite this article as: Telenti: Clinical use of pharmacogenomics.

Retrovirology 2012 9(Suppl 1):12.

Submit your next manuscript to BioMed Central and take full advantage of:

- Convenient online submission

- Thorough peer review

- No space constraints or color figure charges

- Immediate publication on acceptance

- Inclusion in PubMed, CAS, Scopus and Google Scholar

- Research which is freely available for redistribution

Submit your manuscript at www.biomedcentral.com/submit

\section{() Biomed Central}

\section{Biomed Central}

(c) 2012 Telenti; licensee BioMed Central Ltd. This is an Open Access article distributed under the terms of the Creative Commons Attribution License (http://creativecommons.org/licenses/by/2.0), which permits unrestricted use, distribution, and reproduction in any medium, provided the original work is properly cited. 